\title{
THE EFFECT OF CROPS CULTIVATION ON SOIL EROSION INDICES BASED ON IMPELERO MODEL IN NORTHEAST IRAN
}

\author{
AFSHAR, E. ${ }^{1}-$ YARNIA, M. ${ }^{*}-$ BAGHERZADEH, A. $^{2}-$ MiRSHEKARI, B. ${ }^{1}-$ HAGHIGHI, R. S. ${ }^{2}$ \\ ${ }^{1}$ Department of Agronomy and Plant Breeding, Tabriz Branch, Islamic Azad University, \\ Tabriz, P.O. Box 5157944533, Iran \\ ${ }^{2}$ Department of Agriculture, Mashhad Branch, Islamic Azad University, \\ Mashhad, P.O. Box 91735413, Iran \\ *Corresponding author \\ e-mail: m.yarnia@yahoo.com; phone: +98-914-116-7065 \\ (Received $4^{\text {th }}$ Sep 2017 ; accepted $11^{\text {th }}$ Jan 2018)
}

\begin{abstract}
In the present study an integrated neural network based model named ImpelERO was applied to estimate the impact of conventional cropping system on erosion indices, including soil vulnerability index, erosion risk class and soil loss rates by potato, alfalfa and maize plantations. Our results revealed that the soil vulnerability indices ranged from 0.21 to $0.52,0.15$ to 0.41 and 0.2 to 0.5 by potato, alfalfa and maize cultivations, respectively. The values of erosion risk classes by potato and maize cultivation ranged from V1 to V4 in which categorize the region as non-sensitive to very sensitive to erosion and by alfalfa cultivation varied between V1 to V3 which classify the study area as non-sensitive to sensitive to erosion The values of soil losses varied between 7.1 to $59 \mathrm{t} \mathrm{ha}^{-1} \mathrm{yr}^{-1}$ with an average of $15.11 \mathrm{t} \mathrm{ha}^{-1} \mathrm{yr}^{-1}$ by potato, 4.9 to $32.4 \mathrm{t} \mathrm{ha}^{-1} \mathrm{yr}^{-1}$ with an average of $8.42 \mathrm{t} \mathrm{ha}^{-1} \mathrm{yr}^{-1}$ by alfalfa and 6.8 to $52.7 \mathrm{tha}^{-1} \mathrm{yr}^{-1}$ with an average of $13.65 \mathrm{t} \mathrm{ha}^{-1} \mathrm{yr}^{-1}$ by maize cultivation. It was concluded that planting perennial alfalfa compared to row planted potato and maize has a great effect on controlling soil erosion and its indices at the study area.
\end{abstract}

Keywords: neural network, erosion, potato, alfalfa, maize, GIS

\section{Introduction}

Nowadays, soil erosion issues are considered one of the most important topics in the management of agriculture, natural resources, the environment, and water resources; which is the comprehensive management of watershed areas. The extent of soil erosion is determined by numerous factors such as relief, soil type, precipitation, farming practices, etc. (Evans, 2002). While soil and relief characteristics of fields have little change from year to year, precipitation and farming practices may vary strongly over time. The time-dependent combined effects of precipitation and cultivation practices and crop patterns are crucial for soil erosion in any given area (Fiener et al., 2011). The plant cover and cultivation practices are among the most important factors explaining the intensity of soil erosion, comparing rainfall intensity and slope gradient (Kosmas et al., 1997; Wainwright and Thornes, 2004). A number of studies demonstrate that the erosion caused by conventional tillage practices results in increased soil erosion, reduced surface soil quality on curving slope positions, loss of soil organic matter, revelation of subsoil with low quality and increased spatial variability of crop production (Kosmas et al., 2001; Papiernik et al., 2005). It has been shown that the main driving force for the soil redistribution is the erosion caused by conventional tillage practices which is strongly associated with the soil properties and grain yields (Quine and Zhang, 2002). Tillage erosion is the redistribution of soil within a farm caused directly by tillage. It has been shown that tillage erosion is a potential contributor to the 
total soil erosion on cultivated fields (Govers et al., 1999). The importance of tillage translocation on erosion in cultivated areas have been studied worldwide (Govers et al., 1999; Van Muysen et al., 2000, 2002; Lindstrom et al., 2001; de Alba et al., 2006; Van Oost et al., 2006). In recent decades much effort has been put into understanding the mechanisms of soil erosion by studying the factors affecting soil loss. In this regard several empirical or process-based models have been developed and practiced (Merritt et al., 2003; Russell and William, 2001). Modeling studies have mostly been limited to direct impact investigations without considering the potential for increased or even decreased erosion which may result from changes in land use and management (Mullan et al., 2012). Resource degradation is also an important problem for semi-arid areas and water erosion is common (Maji et al., 2010). One of the most important characteristics of precipitation in arid and semi-arid regions as the case of the study area is thunderstorm which causes huge runoff in a short time which resulted in massive amount of soil losses. In an investigation by Bagherzadeh (2014) for estimating soil losses in Mashhad-Chenaran Plain, the values of soil losses varied between 0 and $0.25 \mathrm{t}$ $\mathrm{ha}^{-1} \mathrm{yr}^{-1}$ alongside the kashaf-rud river in the middle of the plain and 2-10 $\mathrm{t} \mathrm{ha}^{-1} \mathrm{yr}^{-1}$ at the edges of the plain. Conventional down-slope cultivation on 1-2\% slopes of silty loam soils accelerated the erosion process and adversely influenced soil structure (Kurothe et al., 2014). The Agricultural Soil Erosion Evaluation Model (ImpelERO) as an artificial neural network model developed for prediction of vulnerability to water erosion, productivity reduction and optimal management strategies for an agricultural parcel (de la Rosa et al., 1999). The aim of present study was to investigate the applicability of the proposed approach for predicting agricultural soil erosion vulnerability (ImpelERO model; De la Rosa et al., 1999) in14 selected benchmark sites from Chenaran Plain, northeast Iran was carried out in order to investigate the impact of conventional cultivation system of potato, alfalfa and maize as main strategic crops on soil erosion indices including vulnerability index, Risk class and Soil loss rate.

\section{Materials and methods}

\section{Geographic position of the study area}

The present study was conducted in Chenaran Plain with an area of $1305.3 \mathrm{~km}^{2}$, Khorasan-e-Razavi province, northeast Iran. The study area is located between latitude $36.51^{\circ}$ to $37.07^{\circ} \mathrm{N}$ and longitude $58.38^{\circ}$ to $59.07^{\circ} \mathrm{E}$ including lands less than $1500 \mathrm{~m}$ above sea level (asl). The topographical elevation values of the study area vary between 1131 and $2907 \mathrm{~m}$ asl, while the main topographical elevation range over $2019 \mathrm{~m}$ asl. The general physiographic trend of the plain extends in a NW-SE direction surrounded between two mountainous zones of Kopetdagh at northward and Binaloud at southward based on visual interpretation of satellite image and field observations (Fig. 1).

The database in our study were the soil samples which derived from the Soil and Water Research Center of Khorasan-e-Razavi province, northeast Iran and the climate data were collected from local weather stations in study area. The main land use practice at the study area is irrigated farming around Kashaf-rud River. The study area has a semi-arid climate with mean annual precipitation of $208 \mathrm{~mm}$ and mean annual temperature of $13.5^{\circ} \mathrm{C}$. The rainiest month is March $(46.7 \mathrm{~mm})$ and the driest month is August $(0.7 \mathrm{~mm})$. The soil physical and chemical characteristics and the land terrain of the selected sites have been presented in Tables 1 and 2 . 
Table 1. Soil physical and chemical characteristics of the study area

\begin{tabular}{c|c|c|c|c|c|c|c|c|c}
\hline Site & Longitude & Latitude & Sand & Silt & Clay & Texture & ESP (\%) & OM (\%) & Bulk density \\
\hline 1 & 59.010 & 36.684 & 26 & 62 & 12 & Silt loam & 0.88 & 0.81 & 1.455 \\
2 & 58.935 & 36.749 & 14 & 58 & 28 & Silty clay loam & 6.02 & 1.91 & 1.308 \\
3 & 59.013 & 36.746 & 36 & 60 & 4 & Silt loam & 7.71 & 1.09 & 1.636 \\
4 & 58.782 & 36.818 & 34 & 48 & 18 & Loam & 0.88 & 0.62 & 1.411 \\
5 & 58.861 & 36.815 & 26 & 48 & 26 & Loam & 12.2 & 0.72 & 1.342 \\
6 & 58.939 & 36.812 & 25 & 48 & 27 & Clay loam/loam & 8.59 & 1.03 & 1.334 \\
7 & 58.707 & 36.884 & 34 & 56 & 10 & Silt loam & 0.58 & 0.93 & 1.497 \\
8 & 58.786 & 36.881 & 29 & 49 & 22 & Loam & 13.3 & 0.59 & 1.372 \\
9 & 58.554 & 36.953 & 32 & 52 & 16 & Silt loam & 0.43 & 0.86 & 1.425 \\
10 & 58.633 & 36.950 & 48 & 40 & 12 & Loam & 0.58 & 0.88 & 1.498 \\
11 & 58.711 & 36.947 & 25 & 52 & 23 & Silt loam & 6.42 & 1.84 & 1.358 \\
12 & 58.558 & 37.016 & 32 & 54 & 14 & Silt loam & 0.43 & 1 & 1.444 \\
13 & 58.636 & 37.013 & 30 & 52 & 18 & Silt loam & 0.58 & 0.59 & 1.403 \\
14 & 58.697 & 37.012 & 24 & 58 & 18 & Silt loam & 0.29 & 0.76 & 1.392 \\
\hline
\end{tabular}

Table 2. Land terrain values of the study area

\begin{tabular}{c|c|c|c|c|c}
\hline \multirow{2}{*}{ Site } & \multicolumn{2}{|c|}{ Slope } & \multirow{2}{*}{ Aspect degree } & Sub soil stoniness class $^{2}$ & Internal drainage $^{\mathbf{3}}$ \\
\cline { 2 - 5 } & $\%$ & class $^{\mathbf{1}}$ & & $\mathrm{C}$ & $\mathrm{M}$ \\
\hline 1 & 2.00 & $\mathrm{~A}$ & 3.00 & $\mathrm{C}$ & $\mathrm{V}$ \\
2 & 1.00 & $\mathrm{~F}$ & 3.00 & $\mathrm{C}$ & $\mathrm{M}$ \\
3 & 2.00 & $\mathrm{~A}$ & 3.00 & $\mathrm{C}$ & $\mathrm{M}$ \\
4 & 1.00 & $\mathrm{~F}$ & 5.00 & $\mathrm{~F}$ & $\mathrm{M}$ \\
5 & 1.00 & $\mathrm{~F}$ & 3.00 & $\mathrm{~F}$ & $\mathrm{~V}$ \\
6 & 2.00 & $\mathrm{~A}$ & 7.00 & $\mathrm{~F}$ & $\mathrm{M}$ \\
7 & 1.00 & $\mathrm{~F}$ & 3.00 & $\mathrm{~F}$ & $\mathrm{M}$ \\
8 & 1.00 & $\mathrm{~F}$ & 5.00 & $\mathrm{~F}$ & $\mathrm{M}$ \\
9 & 2.00 & $\mathrm{~A}$ & 3.00 & $\mathrm{~F}$ & $\mathrm{M}$ \\
10 & 2.00 & $\mathrm{~A}$ & 3.00 & $\mathrm{~F}$ & $\mathrm{M}$ \\
11 & 2.00 & $\mathrm{~A}$ & 7.00 & $\mathrm{~F}$ & $\mathrm{M}$ \\
12 & 2.00 & $\mathrm{~A}$ & 3.00 & $\mathrm{~F}$ & $\mathrm{M}$ \\
13 & 2.00 & $\mathrm{~A}$ & 7.00 & $\mathrm{~F}$ & $\mathrm{M}$ \\
14 & 7.00 & $\mathrm{U}$ & 7.00 & & \\
\hline
\end{tabular}

${ }^{1}$ Slope class: F: flat, A: almost flat, U: undul

${ }^{2}$ Sub soil stoniness class: F: few, C: common

${ }^{3}$ Internal drainage: M: moderate, V: very slow

\section{The ImpelERO model}

The data of the soil samples have been extracted from the studies of soil monitoring of Chenaran Plain. Geologically, main alluvial nature of the plain has been developed into a thick sediment dominated environment that belongs to quaternary period. Crop management systems includes farming systems, interactions with crop residue after harvesting, plowing systems during the growing season, row spacing, basic 
functionality and yield prediction as well as the frequency of application and type of equipment used for plowing from planting to harvesting (Table 3).

Table 3. Agricultural management practices for potato, alfalfa and maize cultivation, and assumed to be used in the selected sites

\begin{tabular}{|c|c|c|c|c|c|c|c|c|c|}
\hline \multirow{2}{*}{$\begin{array}{l}\text { Crop } \\
\text { type }\end{array}$} & \multirow{2}{*}{ Managemen } & \multirow{2}{*}{$\begin{array}{c}\text { Residue } \\
\text { treatment }\end{array}$} & \multirow{2}{*}{$\begin{array}{l}\text { Tillage } \\
\text { system }\end{array}$} & \multirow{2}{*}{\begin{tabular}{|c} 
Row \\
spacing \\
(m)
\end{tabular}} & \multirow{2}{*}{$\begin{array}{c}\text { Baseline } \\
\text { yield }^{1} \\
\left.\text { (t ha }^{-1}\right)\end{array}$} & \multirow{2}{*}{$\begin{array}{c}\text { Estimated } \\
\text { yield }^{2} \\
\left(\mathrm{t} \mathrm{ha}^{-1}\right)\end{array}$} & \multicolumn{3}{|c|}{ Tillage operation } \\
\hline & & & & & & & Implement & Time $^{3}$ & ${ }^{3}$ Workability \\
\hline \multirow{7}{*}{ Potato } & \multirow{7}{*}{ Convention } & \multirow{7}{*}{ Grazing } & \multirow{7}{*}{ Traditional } & \multirow{7}{*}{0.6} & \multirow{7}{*}{31} & \multirow{7}{*}{35} & $\begin{array}{c}\text { Plow } \\
\text { moldboard }\end{array}$ & 2 & Yes \\
\hline & & & & & & & $\begin{array}{l}\text { Drill deep } \\
\text { furrow }\end{array}$ & 1 & Yes \\
\hline & & & & & & & $\begin{array}{l}\text { Disc } \\
\text { cultivator }\end{array}$ & 2 & Yes \\
\hline & & & & & & & $\begin{array}{c}\text { Harrow- } \\
\text { roller }\end{array}$ & 3 & Yes \\
\hline & & & & & & & $\begin{array}{c}\text { Planter } \\
\text { row }\end{array}$ & 1 & Yes \\
\hline & & & & & & & $\begin{array}{c}\text { Spray } \\
\text { implement }\end{array}$ & 4 & Yes \\
\hline & & & & & & & $\begin{array}{l}\text { Fertilizer } \\
\text { applicator }\end{array}$ & 3 & Yes \\
\hline \multirow{6}{*}{ Alfalfa } & \multirow{6}{*}{ Convention } & \multirow{6}{*}{ Grazing } & \multirow{6}{*}{ Traditional } & \multirow{6}{*}{0.5} & \multirow{6}{*}{10} & \multirow{6}{*}{12} & $\begin{array}{c}\text { Plow } \\
\text { moldboard }\end{array}$ & 1 & Yes \\
\hline & & & & & & & $\begin{array}{c}\text { Disc } \\
\text { cultivator }\end{array}$ & 2 & Yes \\
\hline & & & & & & & $\begin{array}{c}\text { Harrow- } \\
\text { roller }\end{array}$ & 1 & Yes \\
\hline & & & & & & & $\begin{array}{c}\text { Planter } \\
\text { row }\end{array}$ & 1 & Yes \\
\hline & & & & & & & $\begin{array}{c}\text { Spray } \\
\text { implement }\end{array}$ & 2 & Yes \\
\hline & & & & & & & $\begin{array}{l}\text { Fertilizer } \\
\text { applicator }\end{array}$ & 2 & Yes \\
\hline \multirow{7}{*}{ Maize } & \multirow{7}{*}{ Convention } & \multirow{7}{*}{ Grazing } & \multirow{7}{*}{ Traditional } & \multirow{7}{*}{0.75} & \multirow{7}{*}{40} & \multirow{7}{*}{45} & $\begin{array}{c}\text { Plow } \\
\text { moldboard }\end{array}$ & 1 & Yes \\
\hline & & & & & & & $\begin{array}{l}\text { Drill deep } \\
\text { furrow }\end{array}$ & 1 & Yes \\
\hline & & & & & & & $\begin{array}{c}\text { Disc } \\
\text { cultivator }\end{array}$ & 2 & Yes \\
\hline & & & & & & & $\begin{array}{c}\text { Harrow- } \\
\text { roller }\end{array}$ & 3 & Yes \\
\hline & & & & & & & $\begin{array}{c}\text { Planter } \\
\text { row }\end{array}$ & 1 & Yes \\
\hline & & & & & & & $\begin{array}{c}\text { Spray } \\
\text { implement }\end{array}$ & 2 & Yes \\
\hline & & & & & & & $\begin{array}{l}\text { Fertilizer } \\
\text { applicator }\end{array}$ & 4 & Yes \\
\hline
\end{tabular}

${ }^{1}$ Baseline yield is the actual value of crop production from statistical sources

${ }^{2}$ Estimated yield is the predicted value of crop production by using simulation models

${ }^{3}$ Number of times that an implement is used

${ }^{4}$ Workability status makes reference if (yes or no) the optimum soil water content for each tillage operation is considered by the farmer 


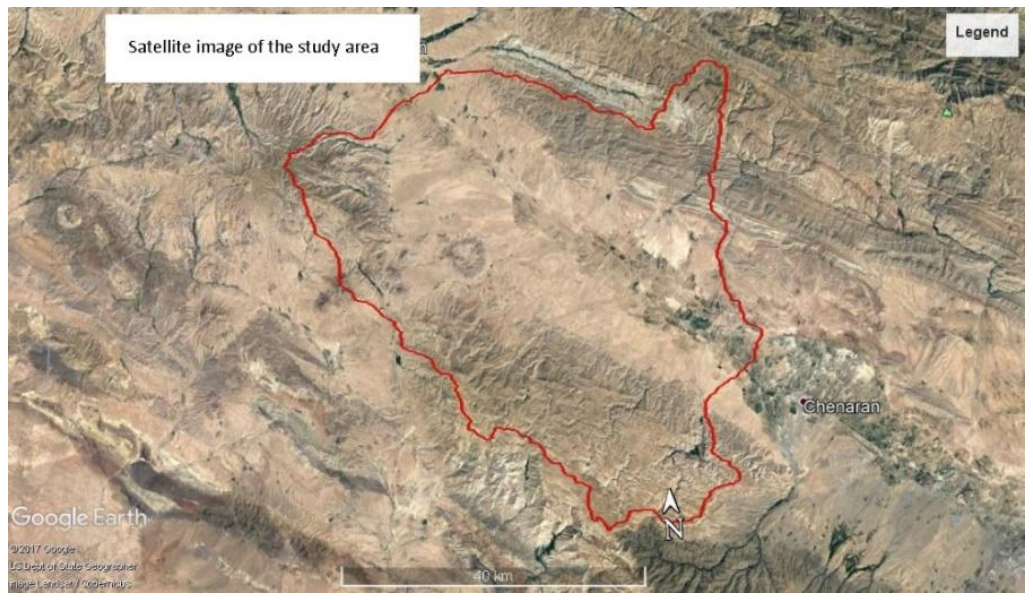

Figure 1. Satellite image of the study area

Soil depth loss was calculated using the ImpelERO model (De la Rosa et al., 1999). This model was developed as a Universal Soil Loss Equation-type model following traditional land evaluation analysis and advanced empirical modelling techniques. Using expertdecision trees, soil survey information and expert knowledge of the soil erosion process were combined with land and management qualities (de la Rosa et al., 2000).

An artificial neural-network approach was applied to capture the interactions between the land and management qualities and one output, vulnerability index to soil erosion. This computerized approach of agricultural management strategies on soil erosion reduction is summarized in Figure 2. As a first step and for one particular fieldunit (fixed land qualities, LQs), the user can establish a percentage of vulnerability reduction $(R)$ of the actual vulnerability index $\left(\mathrm{V}_{\mathrm{a}}\right)$ in order to calculate the target vulnerability index $\left(\mathrm{V}_{\mathrm{t}}\right)$. As a second step, 64 applications of the neural-network (four possible values of the three management qualities, MQs, $=4^{3}$ ) were made in order to calculate the vulnerability index $\left(\mathrm{V}_{\mathrm{j}}\right)$ which is closer to the target index. Then, the combination of MQs which corresponds to the $V_{j}$ was selected. As a third step, the decision trees were backtracked by using the selected combination of MQs to finally formulate the optimum management strategies (de la Rosa et al., 2000).

\section{Spatial analysis}

An IDW interpolation function was applied in GIS to produce interpreted maps and visualize the zonation of the erosion indices including vulnerability index, erosion risk class and soil loss rate in the study area.

\section{Results}

The values of soil vulnerability indices by potato, alfalfa and maize cultivations varied between 0.21 to $0.52,0.15$ to 0.41 and 0.2 to 0.5 , respectively (Table 4). The most vulnerable regions to erosion by potato and maize cultivations were some parts in north and east of the study area, while by alfalfa production the prone areas to high erosion vulnerability restricted to scattered parts in north of the plain (Fig. 3). The value of soil vulnerability index for maize and potato by conventional management system were greater than the similar values by alfalfa cultivation. 


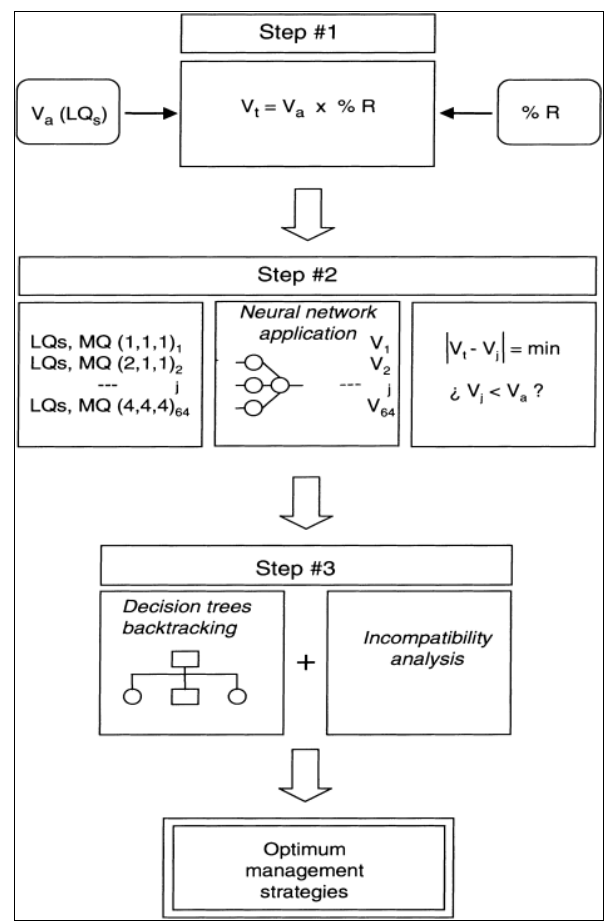

Figure 2. General scheme of the automated neural-network-based search and the decision trees backtracking to accommodate the management practices (MQs= management qualities) to a percent of soil erosion reduction, where $V_{a}=$ actual vulnerability index, $V_{t}=$ target vulnerability index, $R=$ desired vulnerability reduction and $V_{j}=$ possible vulnerabilities for fixed land qualities (LQs) (de la Rosa et al., 2000)

Table 4. Soil erosion parameters by conventional practice for potato, alfalfa and maize cultivation

\begin{tabular}{|c|c|c|c|c|c|c|c|c|c|}
\hline \multirow[b]{2}{*}{ Site } & \multicolumn{3}{|c|}{ Potato } & \multicolumn{3}{|c|}{ Alfalfa } & \multicolumn{3}{|c|}{ Maize } \\
\hline & $\begin{array}{l}\text { Vulnerability } \\
\text { index }^{1}\end{array}$ & $\begin{array}{l}\text { Risk } \\
\text { class }^{2}\end{array}$ & $\begin{array}{c}\text { Soil loss } \\
\text { rate } \\
\left(\mathbf{t} \mathbf{h a}^{-1} \mathbf{y r}^{-1}\right)\end{array}$ & $\begin{array}{c}\text { Vulnerability } \\
\text { index }\end{array}$ & $\begin{array}{l}\text { Risk } \\
\text { class }\end{array}$ & $\begin{array}{c}\text { Soil loss } \\
\text { rate } \\
\left(\mathbf{t} \mathbf{~ h a}^{-1} \mathbf{y r}^{-1}\right)\end{array}$ & $\begin{array}{c}\text { Vulnerability } \\
\text { index }\end{array}$ & $\begin{array}{l}\text { Risk } \\
\text { class }\end{array}$ & $\begin{array}{c}\text { Soil loss } \\
\text { rate } \\
\left(\mathbf{t} \mathbf{h a}^{-1} \mathbf{y r}^{-1}\right)\end{array}$ \\
\hline 1 & 0.25 & V2 & 8.5 & 0.18 & V2 & 5.9 & 0.24 & V2 & 8 \\
\hline 2 & 0.36 & V3 & 24.5 & 0.27 & V2 & 8.9 & 0.35 & V3 & 20.4 \\
\hline 3 & 0.25 & V2 & 8.5 & 0.18 & V2 & 5.9 & 0.24 & V2 & 8 \\
\hline 4 & 0.25 & V2 & 8.5 & 0.18 & V2 & 5.9 & 0.24 & V2 & 8 \\
\hline 5 & 0.25 & V2 & 8.5 & 0.18 & V2 & 5.9 & 0.24 & V2 & 8 \\
\hline 6 & 0.41 & V3 & 36 & 0.31 & V3 & 12.7 & 0.4 & V3 & 31.2 \\
\hline 7 & 0.25 & V2 & 8.5 & 0.18 & V2 & 5.9 & 0.24 & V2 & 8 \\
\hline 8 & 0.25 & V2 & 8.5 & 0.18 & V2 & 5.9 & 0.24 & V2 & 8 \\
\hline 9 & 0.25 & V2 & 8.5 & 0.18 & V2 & 5.9 & 0.24 & V2 & 8 \\
\hline 10 & 0.25 & V2 & 8.5 & 0.18 & V2 & 5.9 & 0.24 & V2 & 8 \\
\hline 11 & 0.21 & V2 & 7.1 & 0.15 & V1 & 4.9 & 0.2 & V2 & 6.8 \\
\hline 12 & 0.25 & V2 & 8.5 & 0.18 & V2 & 5.9 & 0.24 & V2 & 8 \\
\hline 13 & 0.25 & V2 & 8.5 & 0.18 & V2 & 5.9 & 0.24 & V2 & 8 \\
\hline 14 & 0.52 & V4 & 59 & 0.41 & V3 & 32.4 & 0.5 & V4 & 52.7 \\
\hline
\end{tabular}

${ }^{1}$ Vulnerability Index ranged from 0-1

${ }^{2}$ Erosion risk class ranged from V1-V6 


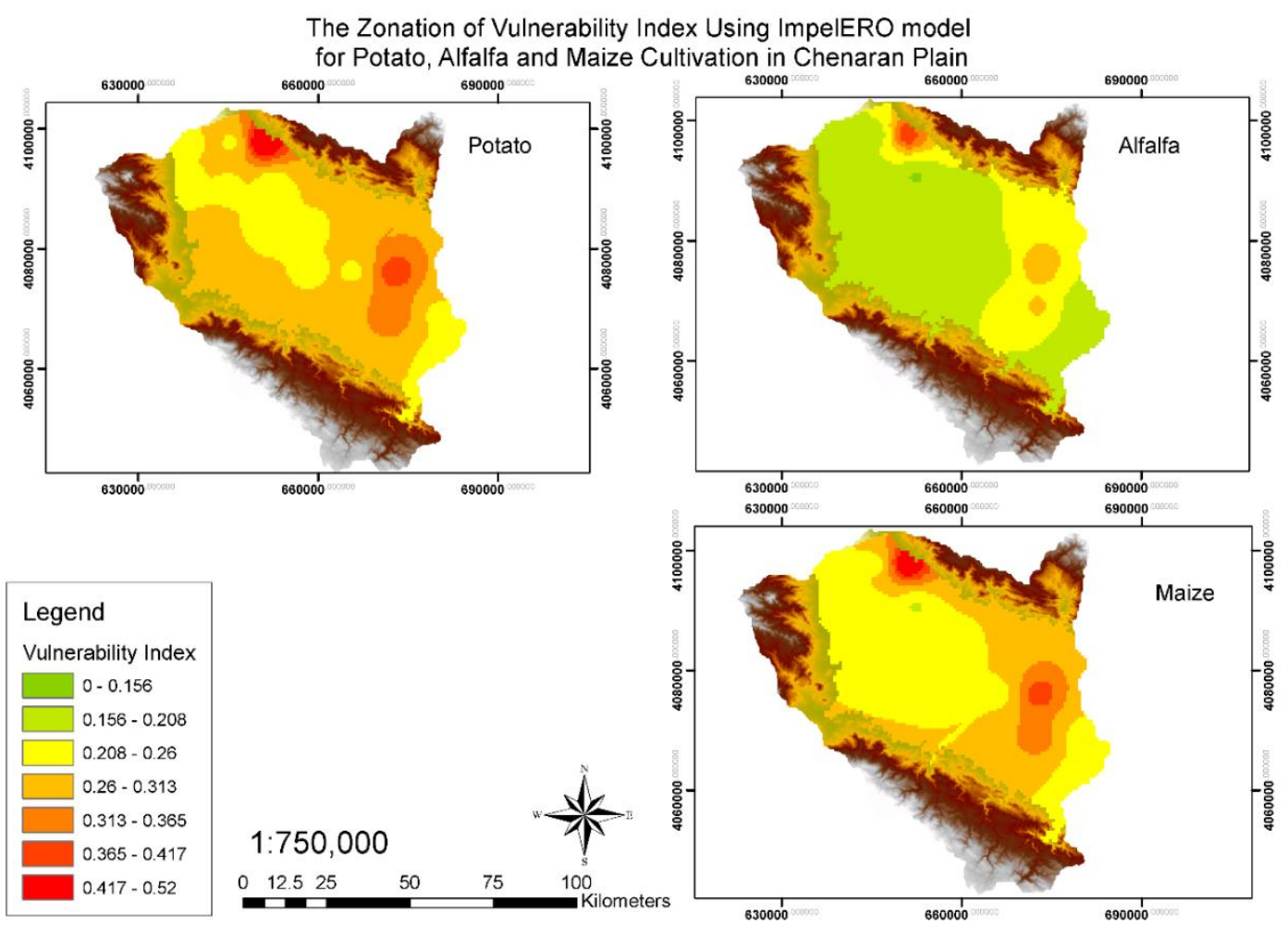

Figure 3. The zonation of vulnerability index for potato, alfalfa and maize cultivation in Chenaran Plain

The zonation map of the erosion risk classes by both potato and maize cultivations revealed that $27.84 \%\left(363.39 \mathrm{~km}^{2}\right)$ of the plain were categorized into $\mathrm{V} 2$ class, $70.63 \%$ $\left(921.98 \mathrm{~km}^{2}\right)$ into $\mathrm{V} 3$ class and $1.53 \%\left(19.93 \mathrm{~km}^{2}\right)$ were classified into V4 risk class. The zonation map of erosion risk class by alfalfa cultivation exhibited that $0.17 \%\left(2.22 \mathrm{~km}^{2}\right)$ of the plain were categorized into V1 class, $79.58 \%\left(1038.82 \mathrm{~km}^{2}\right)$ into V2 class and $20.25 \%\left(264.26 \mathrm{~km}^{2}\right)$ of the study area were classified into V3 risk class (Tables 4 and 5).

Table 5. Measurement areas of zonation map of vulnerability index, erosion risk class and soil loss rate

\begin{tabular}{|c|c|c|c|c|c|c|c|}
\hline & \multicolumn{2}{|c|}{ Potato } & \multicolumn{2}{|c|}{ Alfalfa } & \multicolumn{2}{|c|}{ Maize } \\
\hline & & $\operatorname{Area}\left(\mathrm{km}^{2}\right)$ & $\%$ & $\operatorname{Area}\left(\mathrm{km}^{2}\right)$ & $\%$ & Area $\left(\mathbf{k m}^{2}\right)$ & $\%$ \\
\hline \multirow{7}{*}{$\begin{array}{l}\text { Vulnerability } \\
\text { index }\end{array}$} & $0.0-0.156$ & 0 & 0 & 2.07 & 0.16 & 0 & 0 \\
\hline & $0.156-0.208$ & 0 & 0 & 900.55 & 68.99 & 2.07 & 0.16 \\
\hline & $0.208-0.260$ & 384.72 & 29.47 & 331.09 & 25.37 & 718.71 & 55.06 \\
\hline & $0.260-0.313$ & 749.64 & 57.43 & 54.14 & 4.15 & 450.58 & 34.52 \\
\hline & $0.313-0.365$ & 126.06 & 9.66 & 10.31 & 0.79 & 99.55 & 7.63 \\
\hline & $0.365-0.417$ & 29.06 & 2.23 & 7.14 & 0.55 & 21.52 & 1.65 \\
\hline & $0.417-0.52$ & 15.82 & 1.21 & 0 & 0 & 12.86 & 0.99 \\
\hline \multirow{4}{*}{ Risk class } & V1 & 0 & 0 & 2.22 & 0.17 & 0 & 0 \\
\hline & V2 & 363.39 & 27.84 & 1038.82 & 79.58 & 363.39 & 27.84 \\
\hline & V3 & 921.98 & 70.63 & 264.26 & 20.25 & 921.98 & 70.63 \\
\hline & V4 & 19.93 & 1.53 & 0 & 0 & 19.93 & 1.53 \\
\hline
\end{tabular}




\begin{tabular}{c|c|c|c|c|c|c|c}
\hline & $0.0-5.0$ & 0 & 0 & 0.16 & 0.01 & 0 & 0 \\
& $5.0-10.0$ & 217.54 & 16.67 & 1208.19 & 92.56 & 386.66 & 29.62 \\
& $10.0-15.0$ & 706.97 & 54.16 & 63.19 & 4.84 & 639.99 & 49.03 \\
& $15.0-20.0$ & 222.63 & 17.06 & 13.20 & 1.01 & 184.98 & 14.17 \\
Soil loss rate & $20.0-25.0$ & 86.38 & 6.62 & 9.16 & 0.70 & 45.97 & 3.52 \\
& $25.0-30.0$ & 31.91 & 2.44 & 7.79 & 0.60 & 22.98 & 1.76 \\
& $30.0-35.0$ & 17.77 & 1.36 & 3.61 & 0.28 & 8.25 & 0.63 \\
& $35.0-40.0$ & 6.15 & 0.47 & 0 & 0 & 4.21 & 0.32 \\
& $40.0-60.0$ & 15.95 & 1.22 & 0 & 0 & 12.26 & 0.94 \\
\hline Total & & 1305.304 & 100 & 1305.304 & 100 & 1305.304 & 100 \\
\hline
\end{tabular}

The geographical distribution of the erosion risk classes revealed the same pattern for potato and maize cultivations, where most parts of the study area are sensitive to erosion with high vulnerability. In contrast to other crops the risk classes by alfalfa production exhibit relatively low sensitivity in most parts of the plain to erosion (Fig. 4).

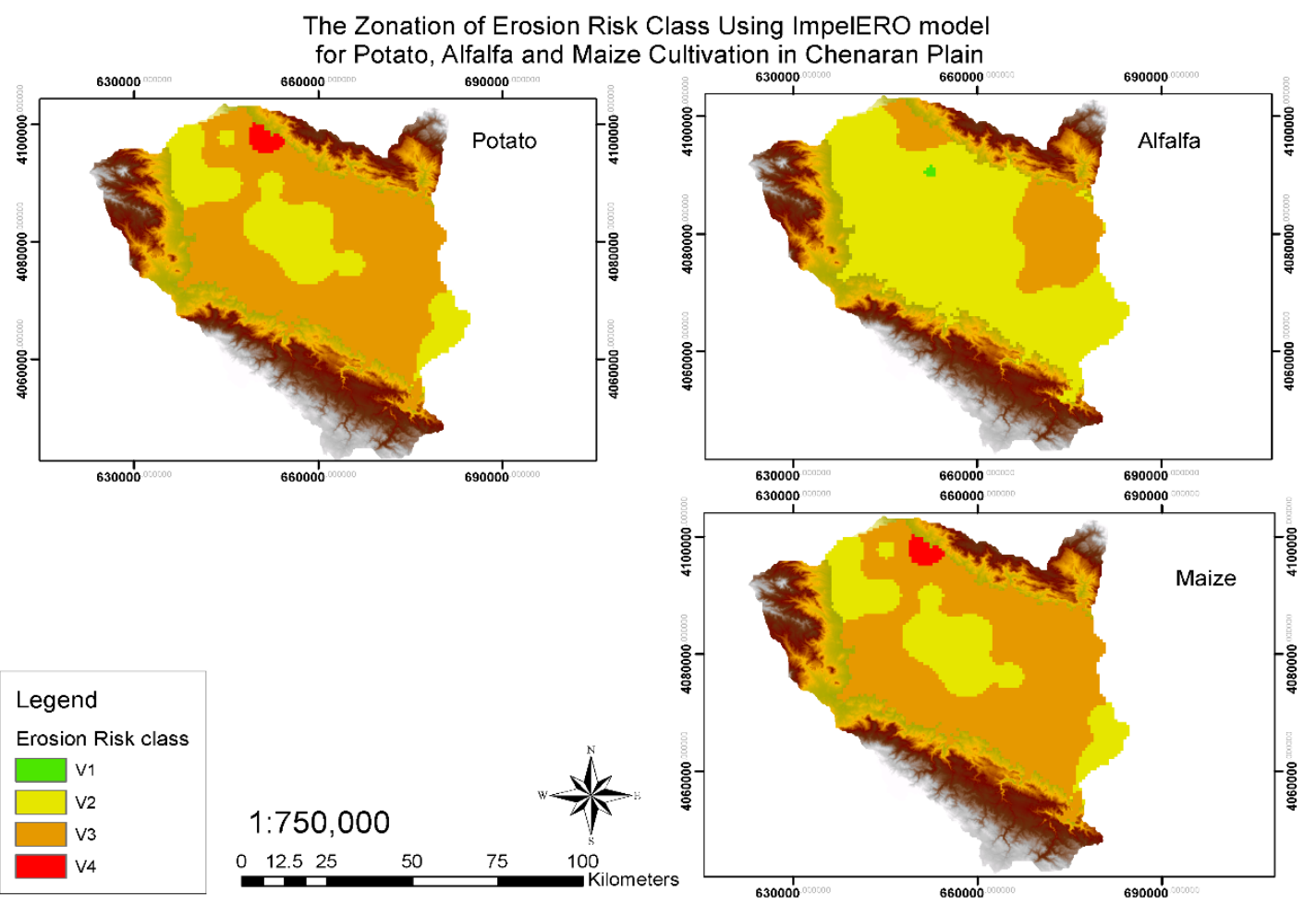

Figure 4. The zonation of erosion risk class for potato, alfalfa and maize cultivation in Chenaran Plain

The values of soil losses varied between 7.1 to $59 \mathrm{t} \mathrm{ha}^{-1} \mathrm{yr}^{-1}$ with an average of $15.11 \mathrm{t} \mathrm{ha}^{-1} \mathrm{yr}^{-1}$ by potato, 4.9 to $32.4 \mathrm{t} \mathrm{ha}^{-1} \mathrm{yr}^{-1}$ with an average of $8.42 \mathrm{t} \mathrm{ha}^{-1} \mathrm{yr}^{-1}$ by alfalfa and 6.8 to $52.7 \mathrm{t} \mathrm{ha}^{-1} \mathrm{yr}^{-1}$ with an average of $13.65 \mathrm{t} \mathrm{ha}^{-1} \mathrm{yr}^{-1}$ by maize cultivation (Table 4 and Fig. 5). 


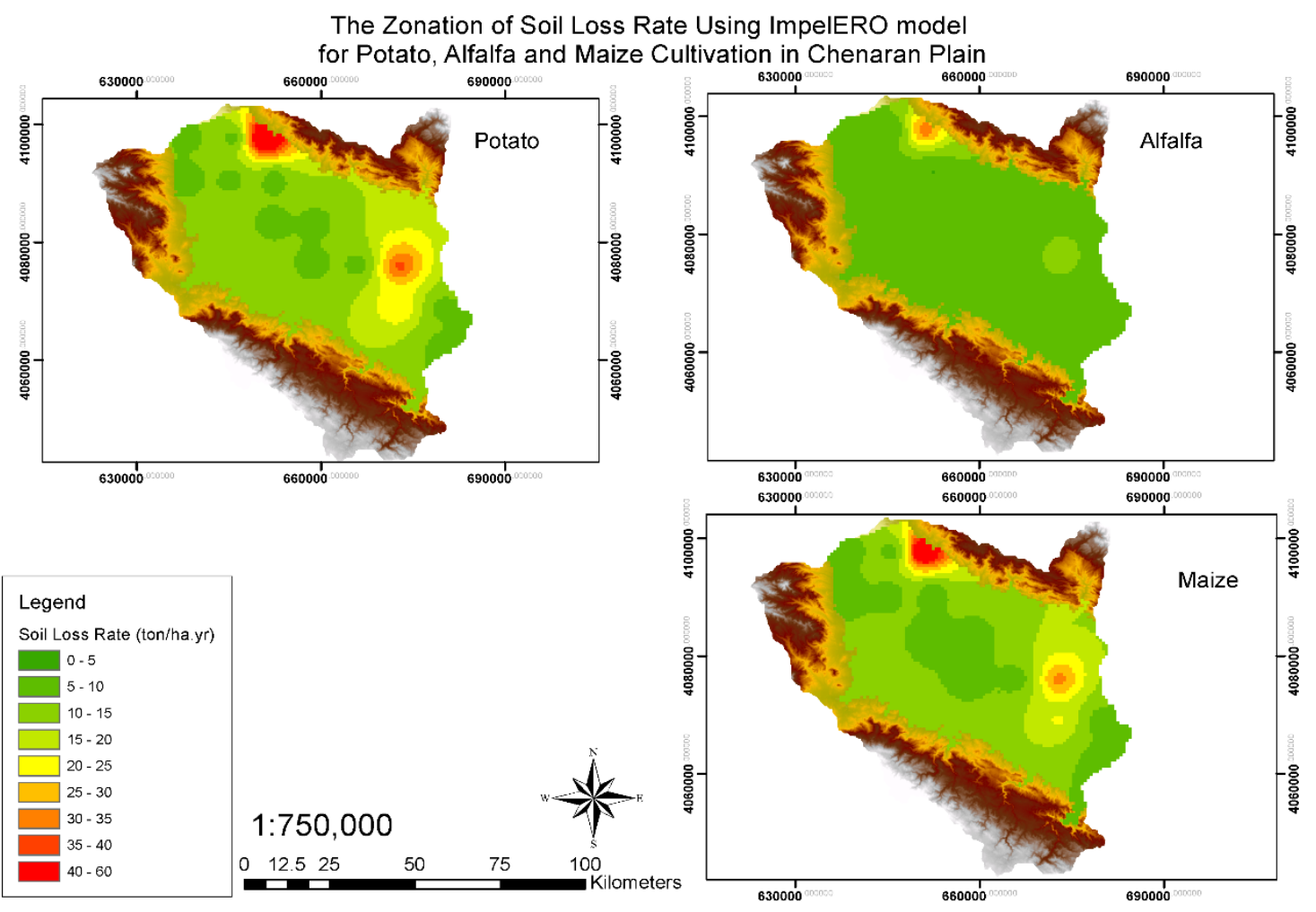

Figure 5. The zonation of soil loss rate for potato, alfalfa and maize cultivation in Chenaran Plain

As shown above, the values of soil losses by potato and maize cultivations were higher than the corresponding values by alfalfa cultivation. The reduction percent of soil losses by maize production compared to potato cultivation was about $9.66 \%$, while by alfalfa cultivation the soil losses reduction reached to $44.28 \%$ compared to potato production. Shifting cultivation from maize to alfalfa resulted in $38.32 \%$ reduction in soil losses.

Our results revealed that the effect of row crops cultivation including potato and maize on undulated slopes in mainly southward aspects, medium to fine silty soil textures, the drainage is very slow and the soil organic matter is commonly low in some parts at the north and east of the plain were considered as the most important factors increasing soil vulnerability to erosion, soil loss rates and erosion risk classes.

\section{Discussion}

Results showed that all three erosional classes are moderate in the region, and alfalfa cultivation displays a lower erosional class compared to potato and maize cultivations. Soils with silt and fine sandy texture were the most erodible soils due to their lack of both the cohesiveness of clay minerals and the weight of large particles (Morgan, 2005).

The row crops such as potato and maize plants are highly susceptible to erosion because the vegetation does not cover the entire soil surface (Southgate and Whitaker, 1992; Stone and Moore, 1997).

Our results showed that alfalfa cultivation provides better protection against soil erosion compared with our previous study on sugar beet cultivation (Afshar et al., 2016). Cultivation of potatoes has been reported to be accompanied by enhanced tillage 
erosion and soil loss (Ruysschaert et al., 2006; Auerswald et al., 2006; Evans, 2002). Evans (2002) observed a soil loss rate of $2.53 \mathrm{t} \mathrm{ha}^{-1} \mathrm{yr}^{-1}$ by potato cultivation. Jung et al. (2003) found an average erosion rate of $47.5 \mathrm{t} \mathrm{ha}^{-1} \mathrm{yr}^{-1}$, and Choi et al. (2005) reported erosion rates between $4.2 \mathrm{t} \mathrm{ha}^{-1} \mathrm{yr}^{-1}$ and $29.6 \mathrm{t} \mathrm{ha}^{-1} \mathrm{yr}^{-1}$ by potato cultivation. Potato fields also have a high erosion risk after harvesting because the crop leaves little residue or the residues are ploughed into the soil. Ruysschaert et al. (2006) reported that extensive soil loss may occur if the harvested potato field would not immediately planted with a subsequent crop. Maize cultivation has also a high erosion risk because of its slow early growth and large row spacing (Boardman and Poesen, 2006). Evans (2002) found the contributions of maize on soil loss to $4.48 \mathrm{tha}^{-1} \mathrm{yr}^{-1}$.

The time-dependent combined effects of precipitation and state of the crop fields with regard to the crop planted, soil cover, soil tillage, and soil looseness are crucial for soil erosion in any given area (Fiener et al., 2011). Boardman et al. (2009) reported on serious erosion on fields with post-harvest potato and maize crops in the United Kingdom.

Maize was most frequently affected by erosion. Erosion was greatest by far when the land was planted with potatoes. Thus, crops may show differences in their impact on erosion, but crop sequences and crop rotations should also be taken into account, because positive and negative carry-over effects of previous crops may have an influence on the extent of erosion. As well, the areas which covered by grass-clover as main and intermediate crop markedly decreased the extent of erosion relative to the other crops and winter fallow (Prasuhn, 2012).

\section{Conclusion}

Agricultural activities, especially those concerning soil tillage, can be accommodated to reduce soil erosion by using expert system/neural-network technologies adapted to erosion prediction risks. An example of these models has been satisfactorily used as an optimization tool for selecting the land use and management practices for the reduction of soil erosion. Applying ImpelERO model in estimating soil erosion indices is considered as practical approach to optimize soil use and preventing soil loss. With respect to obtained results we can identify vulnerable areas to erosion and manage the cultivation techniques in order to reduce the values of soil vulnerability and controlling the risk of erosion. According to the ImpelERO model application in benchmark sites of Chenaran Plain, there is a significant vulnerability to soil erosion in some parts in north and east of the study area. It was exhibited that shifting crop pattern to alfalfa cultivation is considered as an alternative in controlling erosion in more vulnerable areas of Chenaran Plain. The cultivation of alfalfa as a perennial plant improves the soil structure, increases organic matter content of the soil and enhance the soil's biological activities. The decreasing effect of alfalfa on soil erosion is primarily based on its longlasting growing period and extensive canopy which cause the subsequent crops may benefit from improved fertility conditions even up to many years later.

Acknowledgement. We thank Islamic Azad University, Tabriz branch for their support of the project. Thanks also to one anonymous reviewer for suggestions on data analyses and interpretations. 


\section{REFERENCES}

[1] Afshar, E., Yarnia, M., Bagherzadeh, A., Sadrabadi Haghighi, R., Mirshekari, B. (2016): The effects of cropping systems on soil erosion risks and crop productivity using ImpelERO model and GIS in northeast of Iran. Model. - Earth Syst. Environ 2: 164.

[2] Auerswald, K., Gerl, G., Kainz, M. (2006): Influence of cropping system on harvest erosion under potato. - Soil Till. Res. 89: 22-34.

[3] Bagherzadeh, A. (2014): Estimation of soil losses by USLE model using GIS at Mashhad plain, Northeast of Iran. - Arab. J. Geosci. 7: 211-220.

[4] Boardman, J., Poesen, J. (2006): Soil Erosion in Europe: Major Processes Causes and Consequences. - In: Boardman, J., Poesen, J. (eds.) Soil Erosion in Europe. Wiley, Chicheste.

[5] Boardman, J., Shepheard, M. L., Walker, E., Foster, I. D. L. (2009): Soil erosion and risk assessment for on- and off-farm impacts: a test case using the Midhurst area, West Sussex, UK. - J. Environ. Manage. 90: 2578-2588.

[6] Choi, J., Choi, Y., Lim, K., Shin, Y. (2005): Soil Erosion Measurement and Control Techniques. - In: Chung, N., Kim, W., Kim, H., Kim, J., Eom, K., Lee, I. (eds.) Proc. International Workshop on Newly Developed Innovative Technology for Soil and Water Conservation. Rural Development Administration.

[7] De Alba, S., Borselli, L., Torrie, D., Pellegrini, S., Bazzoffi, P. (2006): Assessment of tillage erosion by moldboard plough in Tuscany (Italy). - Soil Tillage Res. 85: 123-142.

[8] De la Rosa, D., Mayol, F., Moreno, J. A., Bonson, T., Lozano, S. (1999): An expert system/neural network model (ImpelERO) for evaluating agricultural soil erosion in Andalusia region, southern Apain. - Agriculture, Ecosystems \& Environment 73: 211226.

[9] De la Rosa, D., Moreno, J. A., Mayol, F., Bonson, T. (2000): Assessment of soil erosion vulnerability in western Europe and potential impact on crop productivity due to loss of soil depth using the ImpelERO model. - Agriculture, Ecosystems \& Environment 81: 179-190.

[10] Evans, R. (2002): An alternative way to assess water erosion of cultivated land field based measurements and analysis of some results. - Appl. Geogr. 22: 187-208.

[11] Fiener, P., Auerswald, K., Van Oost, K. (2011): Spatio-temporal patterns in land use and management affecting surface runoff response of agricultural catchments - a review. Earth Sci. Rev. 106: 92-104.

[12] Govers, G., Lobb, D. A., Quine, T. A. (1999): Tillage erosion and translocation emergence of a new paradigm in soil erosion research. - Soil Till. Res. 51: 167-174.

[13] Jung, K., Son, Y., Hur, S., Ha, S., Jang, Y., Jung, P. (2003): Estimation of Nationalwide Soil Loss with Soil Type. - Research Report. National Academy of Agricultural Science (NAAS).

[14] Kosmas, C., Danalatos, N., Cammeraat, L. H., Chabart, M., Diamantopoulos, J., Farand, R., Gutiérrez, L., Jacob, A., Marques, H., Martínez-Fernández, J., Mizara, A., Moutakas, N., Nicolau, J. M., Oliveros, C., Pinna, G., Puddu, R., Puigdefábregas, J., Roxo, M., Simao, A., Stamou, G., Tomasi, N., Usai, D., Vacca, A. (1997): The effect of land use on runoff and soil erosion rates under Mediterranean conditions. - Catena 29: 45-59.

[15] Kosmas, C., Gerontidis, S., Marathianou, M., Detsisa, B., Zafiriou, T., Van Muysen, W., Govers, G., Quine, T. A., Vanoost, K. (2001): The effects of tillage displaced soil on soil properties and wheat biomass. - Soil Till. Res. 58: 31-44.

[16] Kurothe, R. S., Kumar, G., Singh, R., Singh, H. B., Tiwari, S. P., Vishwakarma, A. K., Sena, D. R. Pande, V. C. (2014): Effect of tillage and cropping systems on runoff, soil loss and crop yields under semiarid rainfed agriculture in India. - Soil \& Tillage Research 140: 126-134.

[17] Lindstrom, M. J., Lobb, D. A., Schumacher, T. E. (2001): Tillage erosion: an overview. Ann. Arid Zone 40: 337-349. 
[18] Maji, A. K., Reddy, G. P. O., Sarkar, D., (2010): Degraded and Wasteland of India Status and Spatial Distribution. - ICAR, New Delhi.

[19] Merritt, W. S., Letcher, R. A., Jakeman, A. J. (2003): A review of erosion and sediment transport models. - Environmental Modelling \& Software 18: 761-799.

[20] Morgan, R. P. C., 2005. Soil Erosion and Conservation, 3rd ed. - Blackwell, Malden.

[21] Mullan, D., Favis-Mortlock, D., Fealy, R. (2012): Addressing key limitations associated with modelling soil erosion under the impacts of future climate change. - Agric. For. Meteorol. 156: 18-30.

[22] Papiernik, S. K., Lindstrom, M. J., Schumacher, J. A., Farenhorst, A., Stephans, K. D., Schumacher, T. E., Lobb, D. A. (2005): Variation in soil properties and grain yield across an eroded prairie landscape. - J. Soil Water Conserv. 60: 388-395.

[23] Prasuhn, V. (2012): On-farm effects of tillage and crops on soil erosion measured over 10 years in Switzerland. - Soil \& Tillage Research 120: 137-146.

[24] Quine, T. A., Zhang, Y. (2002): An investigation of spatial variation in soil erosion, soil properties, and crop production within an agricultural field in Devon, United Kingdom. J. Soil Water Conserv. 57: 55-65.

[25] Russell, S. H., William, W. D. (2001): Landscape Erosion and Evolution Modelling. Kluwer Academic/Plenum Publishers: New York, NY.

[26] Ruysschaert, G., Poesen, J., Verstraeten, G., Govers, G. (2006): Soil loss due to mechanized potato harvesting. - Soil Till. Res. 86: 52-72.

[27] Southgate, D., Whitaker, M. (1992): 'Promoting resource degradation in Latin America: Tropical deforestation', soil erosion, and coastal ecosystem disturbance in Ecuador. Economic Development and Cultural Change 40(4): 787-807.

[28] Stone, R. P., Moore, N. (1997): Control of Soil Erosion. Factsheet. http://www.gov.pm.ca/OMAFRA/english/crops/facts/95-089.htm (12/18/2002).

[29] Van Muysen, W., Govers, G., Van Oost, K. (2002): Identification of important factors in the process of tillage erosion: the case of mouldboard tillage. - Soil Tillage Res 65: 7793.

[30] Van Muysen, W., Govers, G., Van Oost, K., Van Rompaey, A. (2000): The effect of tillage depth, tillage speed and soil condition on chisel tillage erosivity. - J. Soil Water Conserv 55: 355-364.

[31] Van Oost, K., Govers, G., de Alba, S., Quine, T. A. (2006): Tillage erosion: a review of controlling factors and implications for soil quality. - Prog. Phys. Geo. 30: 443-466.

[32] Wainwright, J., Thornes, J. B. (2004): Environmental Issues in the Mediterranean. Processes and Perspectives from the Past and Present. - Routledge, London. 